\title{
Kerentanan Species Ikan Retain pada Perikanan Tuna dari Alat Tangkap Handline
}

\section{Vulnerability of Retain Fishes Catch at Tuna Fisheries from Handline Fishing}

\author{
Yonvitner $^{1,2^{*}}$, Mennofatria Boer ${ }^{1)}$, Rahmat Kurnia ${ }^{1)}$, Masykur Tamanyira ${ }^{3)}$ \\ 1) Departemen Manajemen Sumberdaya Perairan, Fakultas Perikanan dan Ilmu Kelautan IPB \\ 2) Pusat Kajian Sumberdaya Pesisir dan Lautan LPPM IPB. \\ 3) Peneliti World Wildlife Fund-Indonesia, Jakarta \\ *Correspondensi Author: yonvitr@yahoo.com
}

\begin{abstract}
Retain fish groups caught in tuna fisheries are also among the main commercial groups that catch by fishermen. The decline in tuna hook rate also affects tuna fisheries including bycatch. For this reason, research on the susceptibility of retain species is needed to ensure its sustainability. The study was conducted in July 2013 in Sendangbiru Malang, Bitung, Wakatobi, and Kendari. Data collected were productivity and susceptibility, and then analyzed according to the MSC (Marine Steward Council) criterias. The vulnerability index was evaluated using the distance index (Jaccard Index). The catches of retain fish from tuna fisheries were skipjack (Katsuwonus pelamis), lemadang (Coryphaena hippurus), and baby tuna (Thunnus albacores). The productivity values ranged 1.43-2.14 and classified as moderate to high, and the susceptibility ranged 1.13-1.48. The vulnerability level of retain fish ranged 86.3 to 96.2 which was classified as low risk and potential to sustain.
\end{abstract}

Kata Kunci: Handline, Productivity, Retain fish, Susceptability, Vulnerability

\begin{abstract}
ABSTRAK
Kelompok ikan retain dari perikanan tuna juga termasuk kelompok komersial utama yang juga banyak dimanfaatkan. Penurunan hook rate tuna juga turut mempengaruhi perikanan tuna termasuk hasil tangkapan samping lainnya. Untuk itu penelitian kerentanan kelompok retain ini juga perlu dilakukan untuk mengetahui potensi berkelanjutannya. Penelitian dilakukan pada bulan Juli 2013 di Sendangbiru Malang, Bitung, Wakatobi, dan Kendari. Data yang dikumpulkan dan kemudian dianalisis adalah produkitivitas dan susceptabilitas menurut kriteria MSC (Marine Steward Council). Indek kerentanan dievaluasi dari indek jarak (Index Jaccard). Hasil tangkapan ikan retain dari perikanan tuna adalah ikan cakalang (Katsuwonus pelamis), ikan lemadang (Coryphaena hippurus), dan baby tuna (Thunnus albacores). Nilai produktivitas berkisar 1.43-2,14 tergolong sedang sampai tinggi dan susceptibilitas 1,13-1,48. Tingkat kerentanan ikan retain berkisar 86,3-96,2 yang tergolong rentan rendah (low risk) dan potensial berkelanjutan.
\end{abstract}

Kata Kunci:Kerentanan, Productivitas, Pancing tangan, Retain, Susceptabilitas

DOI: http://dx.doi.org/10.33772/jspi.v5n2. 


\section{PENDAHULUAN}

Ikan tuna merupakan salah satu komoditas ikan komersial tinggi, dan berperan penting dalam perdagangan ikan dunia. Hasil tangkapan ikan tuna Indonesia pada tahun 2009 sekitar 5\% dari total tangkapan ikan laut dunia. Jika dilihat dari nilai penjualannya, maka tuna memiliki nilai jual tertinggi dibandingkan dengan nilai hasil tangkapan lainnya, yakni mencapai $12 \%$ (ISSF, 2009). Namun sekarang kegiatan relatif terbatas karena adanya pembatasan izin penangkapan pada kapal-kapal ikan tuna.

Produksi ikan tuna bersumber dari Samudera Pasifik 68\% dan Samudera Hindia sekitar 22\% dan sisanya $10 \%$ dari Samudera Atlantik dan Laut Mediterania. Adapun komposisi ikan tuna yang tertangkap meliputi Cakalang (Skipjack Tuna) 60\%, Madidihang (Yellow fin tuna) 24\%, Big eye 10\%, dan Albacore 5\%, sisanya adalah tuna sirip biru sekitar $1 \%$. Kondisi yang umum perikanan tuna saat ini lebih didominasi oleh penangkapan baby tuna.

Tingginya kebutuhan dunia juga mendorong peningkatan produksi untuk memenuhi kebutuhan penduduk dunia. Selain itu kesadaran makan ikan juga turut merubah preferensi konsumen dunia dari red meat ke white meat. Bersamaan dengan itu juga terjadi perkembangan alat tangkap jaring (purse seine), sebagai salah satu alat alternatif baru selain pancing (hook and line). Penggunaan alat tangkap baru tersebut memicu tingkat eksploitasi yang makin tinggi yang akhirnya menyebabkan penurunan sumberdaya (stock) tuna dihampir semua perairan lautan (FAO, 2009).

Permintaan yang tinggi dan intensitas yang juga meningkat, mendorong meningkatnya risiko kerentanan (vulnerability) perikanan tuna. Keterancaman perikanan tuna termasuk perikanan baycacth tuna. Salah satu upaya untuk memastikan sustainability perikanan tuna perlu dievaluasi indikator produktivitas dan suceptabilitas sebagai variable penciri penilaiannya. Produktivitas mengacu pada kemampuan untuk pulih secara cepat ketika stoknya berkurang. Sementara itu keterancaman (susceptibility) adalah potensi dipengaruhinya stok oleh adanya aktivitas penangkapan.

Dalam jangkap panjang dapat dipastikan jika pengelolaan tidak dilakukan secara cepat, maka akan menyebabkan terganggunya sustainabilitas perikanan tuna termasuk bycatch tuna. Untuk kajian ini perlu dilakukan agar selalu ada upaya untuk melakukan tindak perbaikan dan dalam pengelolaan perikanan. Untuk penelitian ini bertujuan mengkaji tingkat kerentanan kelompok ikan retain dari perikanan tuna, yang ditangkap menggunakan alat tangkap handlinesehingga diperoleh informasi tingkat kerentanan ikan retain sebagai informasi dasar untuk merumuskan rencana pengelolaan perikanan tuna berkelanjutan

\section{METODE PENELITIAN}

\section{Waktu dan Lokasi}

Penelitian dilaksanakan pada 4-29 Juli 2013 di Pelabuhan Perikanan Samudera (PPS) Kendari dan PPP Sendang Biru Malang, Pelabuhan Nusantara Bitung, dan Pelabuhan Perikanan Wakatobi. Data yang diambil meliputi data primer dan data sekunder. Data hasil wawancara dengan nelayan terkait dengan usaha perikanan tuna untuk mengumpulkan beberapa informasi mengenai teknis penangkapan, sedangkan data sekunder meliputi data produksi dan upaya ikan target tuna dan non target seperti Cakalang, Lemadang, dan Baby tuna yang diperoleh dari lokasi yang dikaji.

\section{Jenis Alat dan Bahan}

Alat yang digunakan antara lain adalah penggaris dengan ketelitian $0,5 \mathrm{~mm}$, timbangan dengan ketelitian $(0,5) \mathrm{g}$, kamera, alat tulis, alat bedah, dan data sheet, sedangkan bahan yang digunakan dalam penelitian ini adalah ikan contoh yang berasal dari lokasi penelitian serta pengawet berupa formalin $4 \%$.

\section{Metode Pengambilan Data}

Data diambil dari sampel ikan contoh yang diamati yang merupakan ikan non target dari hasil tangkapan perikanan tuna: Pertama ikan-ikan hasil tangkapan sampingan tuna (non target) diidentifikasi dengan cepat (rapid assessment). Selajutnya dilakukan sampling contoh secara acak untuk masing-masing spesies ikan berdasarkan ukuran ikan. Jumlah ikan contoh yang diambil mewakili ukuran ikan yang ada di lokasi tersebut. Hasil tangkapan ikan tuna dikelompokan yaitu ikan umpan, retain, dan 
ETP, kemudian diukur panjang dan beratnya. Ikan contoh yang telah diukur, digunakan sebanyak $10-$ 20 ekor untuk diamati gonadnya sebagai indikator reproduksi. Gonad dipreservasi untuk diamati nilai fekunditas dan diamater telurnya di Laboratorium. Biologi Perikanan, Departemen Manajemen Sumberdaya Perairan, IPB.

Data kuisioner dikumpulkan melalui wawancara langsung dengan nelayan tuna dan pihak terkait diantaranya pengurus koperasi dan Dinas Perikanan dan Kelautan setempat./, Data yang dikumpulkan meliputi data jenis alat tangkap, jenis kapal, operasi penangkapan, daerah fishing ground, harga jual, pendapatan nelayan, jenis ikan lain yang ikut tertangkap dari kelompok ikan retain.

\section{Analisis Produktivitas dan Suceptabilitas}

Parameter yang dikaji diantaranya produktivitas dan susceptibilitas (keterancaman) dengan analisis menggunakan pendekatan yang dikembangkan MSC (Marine Steward Council). Beberapa parameter produktivitas yang dikumpulkan seperti: panjang, umur, tingkat pertumbuhan, fekuditas, rekruitmen, dan kematian alamiah. Setiap atribut produktivitas dinilai dalam tiga skala resiko: rendah (3), sedang (2), atau tinggi (1) (Tabel 1). Keterancaman (susceptibilitas) terdiri atas empat indikator yaitu ketersediaan, encounterability (kemampuan menghadapi), selektivitas, dan kematian pasca penangkapan (PCM). Keempat atribut keterancaman yang dinilai pada tiga skala resiko: tinggi (3), sedang (2) atau rendah (1), sesuai (Tabel 2).

Tabel 1. Atribut dan Skor Produktivitas

\begin{tabular}{|l|l|l|l|}
\hline Atribut Produktivitas & \multicolumn{1}{|c|}{$\begin{array}{c}\text { Produktivitas Rendah } \\
\text { (risiko tinggi, score=3) }\end{array}$} & $\begin{array}{l}\text { Produktivitas Medium } \\
\text { (risiko sedang, score=2) }\end{array}$ & $\begin{array}{c}\text { Produktivitas tinggi } \\
\text { (risiko rendah, score=1) }\end{array}$ \\
\hline $\begin{array}{l}\text { Umur rata-rata saat } \\
\text { matang gonad }\end{array}$ & $>15$ tahun & $5-15$ tahun & $<5$ tahun \\
\hline $\begin{array}{l}\text { Umur rata-rata } \\
\text { maksimum }\end{array}$ & $>25$ tahun & $10-25$ tahun & $<10$ tahun \\
\hline Fekunditas & $<100$ telur per tahun & $\begin{array}{l}100-20,000 \text { teluar per } \\
\text { tahun }\end{array}$ & $>20,000$ telur per year \\
\hline $\begin{array}{l}\text { Ukuran rata-rata } \\
\text { maximum }\end{array}$ & $>300 \mathrm{~cm}$ & $100-300 \mathrm{~cm}$ & $<100 \mathrm{~cm}$ \\
\hline $\begin{array}{l}\text { Ukuran rata-rata saat } \\
\text { matang gonad }\end{array}$ & $>200 \mathrm{~cm}$ & $40-200 \mathrm{~cm}$ & $<40 \mathrm{~cm}$ \\
\hline Strategi Reproduksi & Live bearer & Demersal egg layer & Broadcast spawner \\
\hline Trophic Level & $>3.25$ & $2.75-3.25$ & $<2.75$ \\
\hline
\end{tabular}

Skor risiko dikalikan (kemungkinan rentang angka 1-81) dan dikonversi ke skala kisaran (1-3) untuk menghasilkan skor risiko keterancaman keseluruhan. Rata-rata dari skor resiko memberikan nilai produktivitas secara keseluruhan. Perhitungan dapat dilakukan secara otomatis dalam excel workbook PSA untuk MSC. Selain parameter produktivitas, susceptabilitas juga terdiri dari tiga kategori yaitu susceptabilitas rendah, sedang dan tinggi. Pada bagian ini terdapat 4 atribut utama yang dikaji dan diberikan penilaian seperti disajikan pada Tabel 2.

\section{Analisis Kerentanan}

Setiap atribut produktivitas dan suceptability dinilai dalam tiga skala resiko: rendah (3), sedang (2), atau tinggi (1). Score attribute dari setiap spesies kemudian dapat ditampilkan dalam plot scater x-y. Skor kerentanan secara keseluruhan (V) dari stok di hitung menggunakan persamaan jarak Euclidean dengan formulasi sebagai berikut (Patrick, 2009):

$$
V=\sqrt{(p-3)^{2}+(s-1)^{2}}
$$

Dimana; $\mathrm{V}=$ indek vulnerability

$$
\begin{aligned}
& \mathrm{p}=\text { skor index produktivitas } \\
& \mathrm{s}=\text { skor indek suceptabilitas }
\end{aligned}
$$

Kerentanan menurut MSC dibagi dalam kriteria nilai $<60,60-80$, dan $>80$. Apabila indeks memiliki $>80$ maka ikan terlihat resiko rendah dan apabila diantara 60-80 resiko memiliki resiko sedang, dan < 60 memiliki resiko tinggi. 
JURNAL SAINS dan INOVASI PERIKANAN / Journal of Fishery Science and Innovation

Vol. 5, No. 2. 95-105, Juli 2021

Tabel 2. Atribut dan Skor Susceptabilitas (keterancaman)

\begin{tabular}{|c|c|c|c|}
\hline \multirow{2}{*}{$\begin{array}{c}\text { Attribut } \\
\text { Susceptabilitas }\end{array}$} & \multicolumn{3}{|c|}{ Kriteria Susceptabilitas } \\
\hline & $\begin{array}{l}\text { Susceptibility Rendah } \\
\text { (risiko rendah, score=1) }\end{array}$ & $\begin{array}{l}\text { Susceptibility Sedang } \\
(\text { risiko sedang, } \text { score=2) }\end{array}$ & $\begin{array}{l}\text { Susceptibility Tinggi } \\
\text { (risiko tinggi, score=3) }\end{array}$ \\
\hline $\begin{array}{l}\text { Availability 1. Overlap } \\
\text { of species range with } \\
\text { fishery }\end{array}$ & $<10 \%$ overlaping & $10-30 \%$ overlaping & $>30 \%$ overlaping \\
\hline $\begin{array}{l}\text { Encounterability - } \\
\text { Habitat and depth } \\
\text { check (scores vary by } \\
\text { fishery) }\end{array}$ & $\begin{array}{l}\text { Low overlap with fishing } \\
\text { gear }\end{array}$ & $\begin{array}{l}\text { Medium overlap with } \\
\text { fishing gear }\end{array}$ & $\begin{array}{l}\text { High overlap with fishing } \\
\text { gear }\end{array}$ \\
\hline $\begin{array}{l}\text { Selectivity (scores vary } \\
\text { by gear type, this } \\
\text { example is for set } \\
\text { gillnets. }\end{array}$ & $\begin{array}{l}<\text { mesh size, or }>5 \mathrm{~m} \text { in } \\
\text { length }\end{array}$ & $\begin{array}{l}\text { 1-2 times mesh size, } 4-5 \\
m \text { in length }\end{array}$ & $\begin{array}{l}>2 \text { times mesh size, to } \\
\text { say, } 4 \mathrm{~m} \text { in length }\end{array}$ \\
\hline $\begin{array}{l}\text { Post-capture mortality } \\
\text { (scores vary by fishery) }\end{array}$ & $\begin{array}{l}\text { Evidence of post-capture } \\
\text { release and survival }\end{array}$ & Released alive & $\begin{array}{l}\text { Retained species, or } \\
\text { majority dead when } \\
\text { released }\end{array}$ \\
\hline
\end{tabular}

\section{HASIL DAN PEMBAHASAN}

\section{Hasil}

Kerentanan sumberdaya perikanan tuna diurai dari indikator produktivitas dan susceptabilitas untuk jenis yang dikaji. Pada tahap ini dilakukan analisis terhadap perikanan tuna terutama kelompok ikanikan retain yang banyak berasosiasi dengan ikan tersebut. Kedua parameter dikaji secara mendalam untuk masing-masing jenis ikan yang dikaji.

\section{Produktivitas}

Variable dari produktivitas diantaranya adalah ukuran maksimum, koefisien pertumbuhan, ukuran pertama kali matang gonad, umur maksimum, fekunditas, kematian alami, rekruitmen, dan tingkat trofik level (NOAA, 2010), walaupun beberapa variabel tersebut dapat dimodifikasi. Marine Ssteward Council (MSC) melakukan modifikasi untuk kepentingan informasi pendukung seafood supply. Variabel yang menjadi konstrain (kendala) MSC untuk productivitas antara lain adalah age at maturity (umur matang gonad), maximum age (umur maksimum), fekunditas, maksimum size (ukuran maksimum), size at maturity (ukuran matang gonad), strategi reproduksi dan keberadaan dalam tropic level.

Berdasarkan hasil analisis diperoleh panjang maksimum ikan baby tuna adalah sekitar $56 \mathrm{~cm}$, koefisien pertumbuhan $(\mathrm{K})=0,91 /$ tahun, umur maksimum ikan baby tuna adalah 9 tahun, pertumbuhan intrinsik (r) sekitar 1,42 yang berarti ikan baby tuna akan tumbuh secara alami tanpa ada gangguan dari alam maupun kegiatan manusia dengan laju sebesar 1,42/tahun. Jenis ikan ini termasuk kelompok ikan retain yang tumbuh cepat (Fredou, et al 2016) dibandingkan ikan target. Fekunditas atau jumlah telur tuna sebenarnya mencapai lebih dari $10^{4}$, namun untuk baby tuna dalam penelitian ini menunjukan belum matang gonad, ikan tuna memijah satu kali selama musim pemijahan artinya ikan tuna mengeluarkan semua telurnya dalam satu kali musim pemijahan.

Meningkatnya penangkapan kelompok retain tuna selain karena peningkatan konsumsi ikan, juga karena menurunnya kelompok ikan target dan deplesi stok tuna (Davies et al, 2015). Penelitian ini menemukan nilai kematian alami ikan baby tuna $=$ 0,69 . Dari nilai tersebut diperoleh kematian baby tuna akibat penangkapan mencapai 0,85 atau sekitar $85 \%$ (tergolong tinggi). Berdasarkan hasil penelitian pola rekruitmen diperoleh sebesar 20,6., Hal ini menunjukkan bahwa tingkat keberhasilan rekruitment paling besar ikan baby tuna $=20,6 \%$. Ikan tuna pertama kali memijah terjadi pada umur 1,5 tahun Untuk ikan cakalang diperoleh panjang maksimum adalah sekitar $56 \mathrm{~cm}$, koefisien pertumbuhan $(\mathrm{K})=$ 
0,88/ tahun, umur maksimum ikan cakalang adalah 12 tahun, pertumbuhan intrinsik (r) sekitar 2,26 yang berarti ikan cakalang akan tumbuh secara alami tanpa ada gangguan dari alam maupun kegiatan manusia dengan laju sebesar 2,26/tahun dan tergolong tumbuh cepat (Fredou et a., 2016). Fekunditas atau jumlah telur ikan cakalang berkisar 217272-320230. Ikan cakalang memijah satu kali selama musim pemijahan yang artinya ikan cakalang mengeluarkan semua telurnya dalam satu kali musim pemijahan. Nilai kematiannya adalah 0,72. Berdasarkan hasil penelitian pola rekruitmen diperoleh sebesar 20,8. Hal ini menunjukkan bahwa tingkat keberhasilan rekruitment paling besar ikan cakalang adalah sebesar 20,8\%. Ikan ini ditemukan pertama memijah pada umur sekitar 1,3 tahun.

Dari hasil penelitian untuk ikan lemadang diperoleh panjang maksimum adalah sekitar $91 \mathrm{~cm}$, koefisien pertumbuhan $(\mathrm{K})=1,4 /$ tahun, umur maksimum ikan lemadang relatif singkat yakni 4 tahun, pertumbuhan intrinsik (r) sekitar 3,86 yang berarti ikan cakalang akan tumbuh secara alami tanpa ada gangguan dari alam maupun kegiatan manusia dengan laju sebesar 3,86 per tahun dan juga termasuk tumbuh cepat (Fredou et al, 2016). Fekunditas atau jumlah telur ikan lemadang sekitar 47.193-1.422.112 butir, ikan lemadang memijah satu kali selama musim pemijahan artinya ikan cakalang mengeluarkan semua telurnya dalam satu kali musim pemijahan. Nilai kematian alami ikan lemadang adalah 0,85. Berdasarkan hasil penelitian pola rekruitmen diperoleh sebesar 25,78 hal ini menunjukkan bahwa tingkat keberhasilan rekruitment paling besar ikan lemadang adalah sebesar 25,78\%. Ikan lemadang pertama memijah pada umur sekitar 0,4 tahun, ikan ini termasuk ikan yang cepat matang gonad dan pertumbuhannya cepat.

Sementara itu ikan layaran dan pedang memiliki umur matang gonad 4- 6 tahun, umur rata-rata maksimum antara 14-15 tahun dan relatif lebih lambat tumbuh (Fredou et al, 2016), dengan fekunditas antara 4-6,7 juta. Ukuran maksimum dapat mencapai 4,5 meter dengan ukuran awal matang gonad 2,2 meter. Ikan ini termasuk type ikan memijah secara bebas dan telurnya tersebar di perairan. Jadi peluang untuk survive sangat rendah. Ikan dengan pola ini biasanya saat larva atau telur banyak dimangsa oleh ikan lainnya. Termasuk kedalam tropik level yang tinggi yang 4,5.

Kegiatan perikanan dengan alat tangkap handline yang menangkap ikan baby tuna, cakalang, kemadang, layaran termasuk kelompok ikan retain yang juga menjadi prioritas sampingan utama nelayan. Kegiatan perikanan tuna dengan alat tangkap handline juga dapat berpengaruh terhadap populasi ikan ini dan berbeda dengan longline yang biasanya lebih besar potensi tangkapan targetnya (Carruthers et al, 2011). Hasil evaluasi variabel produktivitas ikan-ikan retain dari aktivitas perikanan tuna dengan alat tangkap handline disajikan pada Tabel 3 .

Tabel 3. Produktivitas dari kelompok ikan retain dari alat tangkap handline

\begin{tabular}{|c|c|c|c|c|c|c|c|c|}
\hline Lokasi & Skor & $\begin{array}{c}\text { Umur } \\
\text { rata-rata } \\
\text { saat } \\
\text { matang } \\
\text { gonad }\end{array}$ & $\begin{array}{l}\text { Umur } \\
\text { maksimum } \\
\text { rata rata }\end{array}$ & $\begin{array}{l}\text { Fecunditas } \\
\text { (telur per } \\
\text { year) }\end{array}$ & $\begin{array}{c}\text { Ukuran } \\
\text { rata-rata } \\
\text { maksimum }\end{array}$ & $\begin{array}{c}\text { Rata- } \\
\text { rata } \\
\text { ukuran } \\
\text { saat } \\
\text { matang } \\
\text { gonad }\end{array}$ & $\begin{array}{c}\text { Strategi } \\
\text { Reproduksi }\end{array}$ & $\begin{array}{l}\text { Tropic } \\
\text { Level }\end{array}$ \\
\hline \multirow[b]{3}{*}{$\begin{array}{l}\text { Skor dan } \\
\text { Kriteria }\end{array}$} & 3 & $>15$ years & $>25$ years & $<100$ & $>300 \mathrm{~m}$ & $>200 \mathrm{~cm}$ & Live bearer & $>3.25$ \\
\hline & 2 & 5-15 years & $10-25$ years & $100-20000$ & $100-300 \mathrm{~cm}$ & $40-200 \mathrm{~m}$ & $\begin{array}{l}\text { Demersal } \\
\text { Egg Layer }\end{array}$ & $\begin{array}{l}2.75- \\
3.25\end{array}$ \\
\hline & 1 & $<5$ years & $<10$ years & $>20000$ & $<100 \mathrm{~cm}$ & $<40 \mathrm{~cm}$ & $\begin{array}{l}\text { Broadcast } \\
\text { spawner }\end{array}$ & 2.75 \\
\hline \multirow{4}{*}{ Malang } & Species & \multicolumn{7}{|c|}{ Nilai dari Parameter } \\
\hline & $\begin{array}{l}\text { Thunnus } \\
\text { albacares }\end{array}$ & 1.5 & 9 & $>10000$ & 51 & 73 & $\begin{array}{l}\text { Broadcast } \\
\text { spawner }\end{array}$ & 4.3 \\
\hline & $\begin{array}{l}\text { Coryphaena } \\
\text { hippurus }\end{array}$ & 0.4 & 4 & $\begin{array}{c}47193- \\
1422112 \\
\end{array}$ & 120 & 90 & $\begin{array}{c}\text { Demersal } \\
\text { Egg Layer }\end{array}$ & 4.4 \\
\hline & Katsuwonus & 1.3 & 12 & $217272-$ & 68 & 50 & Broadcast & 3.8 \\
\hline
\end{tabular}


JURNAL SAINS dan INOVASI PERIKANAN / Journal of Fishery Science and Innovation

Vol. 5, No. 2. 95-105, Juli 2021

\begin{tabular}{|c|c|c|c|c|c|c|c|c|}
\hline Lokasi & Skor & $\begin{array}{l}\text { Umur } \\
\text { rata-rata } \\
\text { saat } \\
\text { matang } \\
\text { gonad }\end{array}$ & $\begin{array}{l}\text { Umur } \\
\text { maksimum } \\
\text { rata rata }\end{array}$ & $\begin{array}{c}\text { Fecunditas } \\
\text { (telur per } \\
\text { year) }\end{array}$ & $\begin{array}{c}\text { Ukuran } \\
\text { rata-rata } \\
\text { maksimum }\end{array}$ & $\begin{array}{c}\text { Rata- } \\
\text { rata } \\
\text { ukuran } \\
\text { saat } \\
\text { matang } \\
\text { gonad }\end{array}$ & $\begin{array}{c}\text { Strategi } \\
\text { Reproduksi }\end{array}$ & $\begin{array}{l}\text { Tropic } \\
\text { Level }\end{array}$ \\
\hline & pelamis & & & 320230 & & & spawner & \\
\hline \multirow[b]{3}{*}{ Bitung } & $\begin{array}{l}\text { Coryphaena } \\
\text { hippurus }\end{array}$ & 0.4 & 4 & $\begin{array}{l}38004- \\
50739\end{array}$ & 74 & 65 & $\begin{array}{c}\text { Demersal } \\
\text { Egg Layer }\end{array}$ & 4.4 \\
\hline & $\begin{array}{l}\text { Katsuwonus } \\
\text { pelamis }\end{array}$ & 1.3 & 12 & $\begin{array}{l}217272- \\
318080\end{array}$ & 52 & 50 & $\begin{array}{l}\text { Broadcast } \\
\text { spawner }\end{array}$ & 3.8 \\
\hline & $\begin{array}{l}\text { Thunnus } \\
\text { albacares }\end{array}$ & 1.5 & 9 & $100-150$ & 53 & 45 & $\begin{array}{l}\text { Broadcast } \\
\text { spawner }\end{array}$ & 4.3 \\
\hline \multirow[b]{2}{*}{ Wakatobi } & $\begin{array}{l}\text { Katsuwonus } \\
\text { pelamis }\end{array}$ & 1.3 & 12 & $\begin{array}{l}147583- \\
997012\end{array}$ & 80 & 70 & $\begin{array}{l}\text { Broadcast } \\
\text { spawner }\end{array}$ & 3.8 \\
\hline & $\begin{array}{l}\text { Thunnus } \\
\text { albacares }\end{array}$ & 1.5 & 9 & $\begin{array}{l}10000- \\
20000\end{array}$ & 54 & 30 & $\begin{array}{l}\text { Broadcast } \\
\text { spawner }\end{array}$ & 4.3 \\
\hline \multirow[b]{3}{*}{ Kendari } & $\begin{array}{l}\text { Katsuwonus } \\
\text { pelamis }\end{array}$ & 1.3 & 12 & 80000 & 110 & 45 & $\begin{array}{l}\text { Broadcast } \\
\text { spawner }\end{array}$ & 3.8 \\
\hline & $\begin{array}{l}\text { Istiophorus } \\
\text { indicus }\end{array}$ & 4 & 14 & 40000000 & 455 & 221 & $\begin{array}{l}\text { Broadcast } \\
\text { spawner }\end{array}$ & 4.5 \\
\hline & Istiompax Indica & 6 & 15 & 67000000 & 465 & 250 & $\begin{array}{l}\text { Broadcast } \\
\text { spawner }\end{array}$ & 4.5 \\
\hline
\end{tabular}

\section{Susceptabilitas}

Variabel lain dari kerentanan yang di analisis adalah keterancaman diantaranya adalah availability, encounterability, selectivity, dan post capture. Baby tuna termasuk kelompok ikan dengan over lapping 10$30 \%$, dan tingkat over lapping yang rendah terhadap alat tangkap. Kelompok ikan ini tidak langsung rusak dari alat tangkap, namun secara umum mudah mengalami kematian, dan tingkat survive apabila dilepas ke perairan termasuk rendah. Keadaan yang sama juga terjadi pada ikan lemadang, namum sedikit lebih tahan dan mampu bertahan jika dilepas ke perairan setelah penangkapan. Sementara karakter ikan cakalang hampir sama dengan ikan baby tuna. Kelompok ikan lemadang relatif lebih tahan dan memiliki peluang hidup yang lebih besar jika dilepas kembali ke perairan. Alat tangkap longline memiliki $73 \%$ retain yang lebih tinggi dibandingkan dengan alat tangkap handline (Huang and Liu,2010).

Keterancaman merupakan faktor kerentanan atau kelemahan suatu ikan. Variable ini dievaluasi dari beberapa faktor termasuk diantaranya praktek manajemen yang dilakukan saat ini, pendugaan laju mortalitas penangkapan, mortalitas alami (eksploitasi), tingkah laku spesies seperti perilaku "schooling" dan migrasi musiman serta tingkat "catchability" dari stock, proses penanganan ikan setelah penangkapan, dan selektifitas alat tangkap. Pada Tabel 4. dapat dilihat hasil analisis parameter keterancaman dari ikan baby tuna, cakalang, dan lemadang.

Informasi yang diperoleh untuk parameterparameter tersebut lebih banyak merupakan hasil wawancara dengan nelayan setempat atau informasi data sekunder dari fishbase. Ikan cakalang dan lemadang merupakan ikan yang hidup pada kedalaman yang hampir sama dengan tuna sehingga vertical overlap cukup tinggi. Vertikal overlap sangat tinggi peluangnya pada kisaran suhu 14-22oC dan kedalaman 80-240 m (Hahlbeck, et al, 2017) serta terkait dengan konsumsi makanan (diet overlap) (Williams et al, 2015). Ikan-ikan ini memiliki area overlap tinggi karena $>60 \%$ berada pada daerah penangkapan ikan tuna dan cukup tersebar dari seluruh daerah penangkapan. Ikan tenggiri dan bawal adalah ikan yang hidup bermigrasi dan cenderung bergerombol kecuali untuk ikan semar yang hidupnya soliter namun sering bergerombol dengan ikan tuna atau jenis ikan scrombidae lainnya. 
JURNAL SAINS dan INOVASI PERIKANAN / Journal of Fishery Science and Innovation

Vol. 5, No. 2. 95-105, Juli 2021

Tabel 4. Suceptabilitas kelompok retain dalam perikanan tuna

\begin{tabular}{|c|c|c|c|c|c|}
\hline Daerah & Suceptability & $\begin{array}{c}\text { Availability (area } \\
\text { overlap + fisheries } \\
\text { impacting to stock) }\end{array}$ & $\begin{array}{l}\text { Encounterability } \\
\text { (Vertikal overlap) }\end{array}$ & Selectivity & $\begin{array}{c}\text { Post Capture } \\
\text { mortality }\end{array}$ \\
\hline \multirow{3}{*}{ Malang } & Thunnus albacares & Overlapping between $10-30 \%$ & $\begin{array}{l}\text { Low overlap with fishing } \\
\text { gear }\end{array}$ & $\begin{array}{l}\text { Species unable to break } \\
\text { snood when being landed }\end{array}$ & Majority dead \\
\hline & $\begin{array}{l}\text { Coryphaena } \\
\text { hippurus }\end{array}$ & Overlapping between $10-30 \%$ & $\begin{array}{l}\text { Low overlap with fishing } \\
\text { gear }\end{array}$ & $\begin{array}{l}\text { Species unable to break } \\
\text { snood when being landed }\end{array}$ & Release alive \\
\hline & Katsuwonus pelamis & Overlapping between $10-30 \%$ & $\begin{array}{l}\text { Low overlap with fishing } \\
\text { gear }\end{array}$ & $\begin{array}{l}\text { Species break when being } \\
\text { landed }\end{array}$ & Majority dead \\
\hline \multirow{3}{*}{ Bitung } & $\begin{array}{l}\text { Coryphaena } \\
\text { hippurus }\end{array}$ & Overlapping between $10-30 \%$ & $\begin{array}{l}\text { Low overlap with fishing } \\
\text { gear }\end{array}$ & $\begin{array}{l}\text { Species unable to break } \\
\text { snood when being landed }\end{array}$ & Release alive \\
\hline & Katsuwonus pelamis & Overlapping between $10-30 \%$ & $\begin{array}{l}\text { Low overlap with fishing } \\
\text { gear }\end{array}$ & $\begin{array}{l}\text { Species break when being } \\
\text { landed }\end{array}$ & Majority dead \\
\hline & Thunnus albacares & Overlapping between $10-30 \%$ & $\begin{array}{l}\text { Low overlap with fishing } \\
\text { gear }\end{array}$ & $\begin{array}{l}\text { Species unable to break } \\
\text { snood when being landed }\end{array}$ & Majority dead \\
\hline \multirow{2}{*}{ Wakatobi } & Katsuwonus pelamis & Overlapping between $10-30 \%$ & $\begin{array}{l}\text { Low overlap with fishing } \\
\text { gear }\end{array}$ & $\begin{array}{l}\text { Species break when being } \\
\text { landed }\end{array}$ & Majority dead \\
\hline & Thunnus albacares & Overlapping between $10-30 \%$ & $\begin{array}{l}\text { Low overlap with fishing } \\
\text { gear }\end{array}$ & $\begin{array}{l}\text { Species unable to break } \\
\text { snood when being landed }\end{array}$ & Majority dead \\
\hline \multirow{3}{*}{ Kendari } & Katsuwonus pelamis & Overlapping between $10-30 \%$ & $\begin{array}{l}\text { Low overlap with fishing } \\
\text { gear }\end{array}$ & $\begin{array}{l}\text { Species break when being } \\
\text { landed }\end{array}$ & Majority dead \\
\hline & Istiophorus indicus & Overlapping between $10-30 \%$ & $\begin{array}{l}\text { Low overlap with fishing } \\
\text { gear }\end{array}$ & $\begin{array}{l}\text { Species unable to break } \\
\text { snood when being landed }\end{array}$ & Release survival \\
\hline & Istiompax Indica & Overlapping between $10-30 \%$ & $\begin{array}{l}\text { Low overlap with fishing } \\
\text { gear }\end{array}$ & $\begin{array}{l}\text { Species unable to break } \\
\text { snood when being landed }\end{array}$ & Release survival \\
\hline
\end{tabular}

\section{Pembahasan}

Tekanan terhadap kelompok retain seringkali sama dengan kelompok ikan tuna target. Hasil pengujian penggunaan alat tangkap longline dengan bentuk pancing bulat menunjukan hasil laju tertangkapnya target spesies dengan baycatch relatif sama (Huang et al, 2015). Upaya mitigasi pengurangan baycatch juga tetap diperlukan walaupun harus diawali dengan mengikuti "international governance", seperti isu perdagangan (Gilman 2011) dan lingkungan seperti eco-label (Kirby et al, 2014).

Skor dari parameter produktivitas (Tabel 3) dan susceptabilitas (Tabel 4) diperoleh seperti pada Tabel 5 dan dieskspresikan pada Gambar 1 sebagai bentuk distribusi data kedua parameter tersebut. Nilai skor produktivitas ikan-ikan retain dengan alat tangkap handline yaitu dari jenis ikan baby tuna, lemadang, cakalang, layaran dan ikan pedang dengan skor productivitas berkisar 1.43-2.14,sementara skor total susceptabilitas berkisar 1.13-1.43. Nilai kerentanan menurut indikator NOAA berkisar antara 1.92-2.42 dan berdasarkan kriteria MSC diperoleh hasil antara 86,3-96,2.

Kerentanan bycatch tuna dipelabuhan ratu dengan pendekatan PSA NOAA dari alat tangkap longline juga menunjukan tingkat kerentanan yang rendah (Yonvitner et al, 2018). Pola ini menunjukkan kriteria populasi ini termasuk kedalam kategori resiko kerentanan rendah untuk semua retain. Pengaruh alat tangkap handline hampir sama dengan longline pada perikanan tuna Atlantic (Huang et al 2015), dimana tekanan laju penangkapan relatif sama. Skor akhir MSC lebih besar dari 80 tergolong beresiko rendah. Pada large marine ecosystem tingginya tangkapan retain selain karena penurunan target juga karena adaptasi terhadap iklim yang kemudian relatif sama polanya diantara kelompok pelagis besar (Berhabib et al, 2016).

Kelompok ikan mahi-mahi atau Coryphaena termasuk ikan pelagis besar yang bersifat migratory. Jadi risiko kerentanan bisa juga terjadi karena saat 
ada buangan dilaut dalam, yang biasanya banyak ketika berukuran kecil dan larva (Pasparakis, 2016). Namun populasi dewasa biasanya relatif mampu beradaptasi terhadap perubahan suhu karena distribusi yang luas pada area beriklim tropis (Asch et al, 2018). Selain itu tropical tuna juga relatif adaptif terhadap air hangat, kedalaman perairan dan lingkungan yang anoksik (tidak tercemar) (Arrizabalaga et al, 2015).

Beberapa jenis baycatch lain seperti penyu laut pada alat longline (Bartram, 2010) lebih efektif jika penilaianya dengan pendekatan Baycatch dan Catch
(B/C) rasio. Fredou et al (2017) menyatakan bahwa kelompok Isthioporidae labih rentan dari jenis lainnya yang tercatat dari pendaratan di Kendari. Namun secara umum masih tergolong low vulnerable karena tingkat produktivitas yang tinggi. Hasil tangkapan alat tangkap handline relatif terkontrol, karena secara langsung bisa dikendalikan sejak proses penangkapanya dibandingkan longline apalagi gillnet longline atau rumpon hanyut (DFAD) Lopez et al (2017). Hasil perhitungan disajikan dalam bentuk grafik korelasi dengan tampilan pada Gambar 1.

Tabel 5. Skoring parameter productivity dan susceptabilitas

\begin{tabular}{|c|c|c|c|c|c|c|c|c|c|c|c|c|c|c|c|c|c|c|}
\hline FAMILY & SCIENTIFIC_NAME & 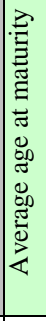 & 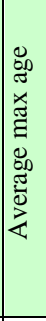 & 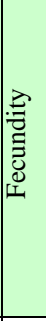 & 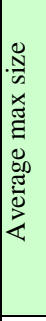 & 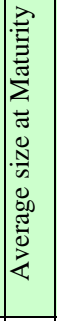 & 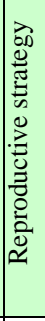 & 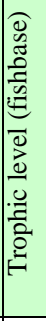 & 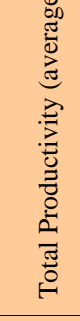 & 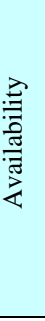 & 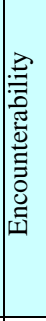 & 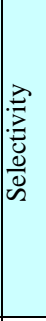 & 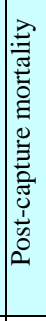 & 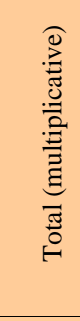 & $\begin{array}{c}\text { PSA } \\
\text { Scor } \\
\text { e }\end{array}$ & $\begin{array}{c}\text { MSC } \\
\text { Scor } \\
\text { e } \\
\end{array}$ & $\begin{array}{l}\text { Risk } \\
\text { Cate } \\
\text { gory } \\
\text { Nam } \\
\text { e }\end{array}$ & $\begin{array}{c}\text { MSC } \\
\text { scori } \\
\text { ng } \\
\text { guid } \\
\text { epost }\end{array}$ \\
\hline Scombridae & Thunus albacares $(\mathrm{m})$ & 1 & 1 & 2 & 1 & 2 & 1 & 3 & 1.57 & 2 & 1 & 3 & 3 & 1.43 & 2.12 & 92.9 & Low & $>80$ \\
\hline Coryphaenidae & Coryphaena hipurus (m) & 1 & 1 & 2 & 2 & 2 & 2 & 3 & 1.86 & 2 & 1 & 3 & 2 & 1.28 & 2.25 & 90.3 & Low & $>80$ \\
\hline Scombridae & Katsuwonus pelamis (m) & 1 & 2 & 1 & 1 & 2 & 1 & 3 & 1.57 & 2 & 1 & 2 & 3 & 1.28 & 2.02 & 94.6 & Low & $>80$ \\
\hline Coryphaenidae & Coryphaena hippurus (b) & 1 & 1 & 1 & 1 & 2 & 2 & 3 & 1.57 & 2 & 1 & 3 & 2 & 1.28 & 2.02 & 94.6 & Low & $>80$ \\
\hline Scombridae & Katsuwonus pelamis (b) & 1 & 1 & 1 & 1 & 2 & 1 & 3 & 1.43 & 2 & 1 & 2 & 3 & 1.28 & 1.91 & 96.2 & Low & $>80$ \\
\hline Scombridae & Thunnus albacares (b) & 1 & 1 & 2 & 1 & 2 & 1 & 3 & 1.57 & 2 & 1 & 3 & 3 & 1.43 & 2.12 & 92.9 & Low & $>80$ \\
\hline Scombridae & Katsuwonus pelamis (wk) & 1 & 2 & 1 & 1 & 2 & 1 & 3 & 1.57 & 2 & 1 & 2 & 3 & 1.28 & 2.02 & 94.6 & Low & $>80$ \\
\hline Scombridae & Thunnus albacares (wk) & 1 & 1 & 1 & 1 & 1 & 1 & 3 & 1.29 & 2 & 1 & 3 & 3 & 1.43 & 1.92 & 96.1 & Low & $>80$ \\
\hline Scombridae & Katsuwonus pelamis $(\mathrm{k})$ & 1 & 2 & 1 & 2 & 2 & 1 & 3 & 1.71 & 2 & 1 & 2 & 3 & 1.28 & 2.14 & 92.6 & Low & $>80$ \\
\hline Isthioporidae & Istiophorus indicus (k) & 1 & 2 & 1 & 3 & 3 & 1 & 3 & 2.00 & 2 & 1 & 3 & 1 & 1.13 & 2.29 & 89.3 & Low & $>80$ \\
\hline Isthioporidae & Istiompax Indica (k) & 2 & 2 & 1 & 3 & 3 & 1 & 3 & 2.14 & 2 & 1 & 3 & 1 & 1.13 & 2.42 & 86.3 & Low & $>80$ \\
\hline
\end{tabular}




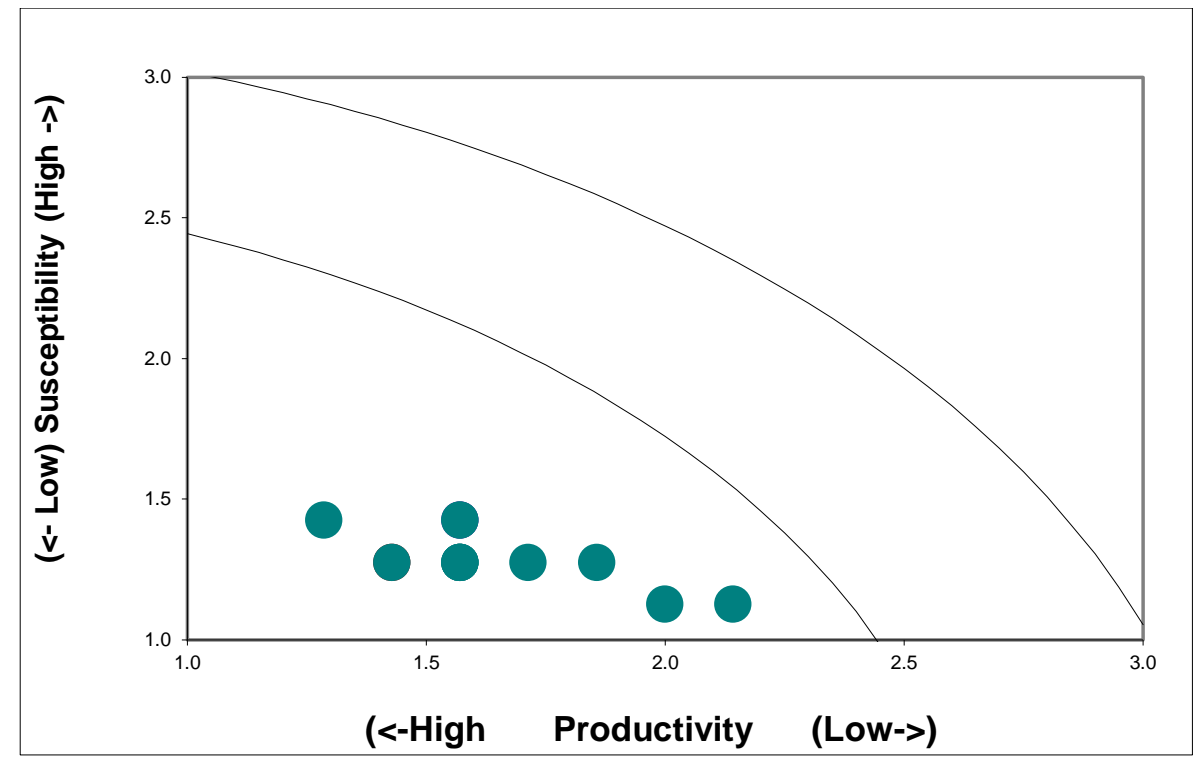

Gambar 1. Kurva PSA ikan-ikan retain dari alat tangkap handline

Dari kurva diatas terlihat bahwa semua jenis ikan di semua lokasi yang ditangkap dengan alat tangkap handline memiliki tingkat produktivitas yang tinggi, dan keterancaman yang rendah. Artinya kondisi ini memberikan indikasi bahwa potensi over eksploitasi masih rendah untuk kelompok ikan retain di keempat wilayah tersebut. Walaupun risiko kerentanan dari jenis jenis ikan yang ada tersebut juga tergolong rendah, namun tetap perlu dipertimbangkan teknik penangkapan yang mengurangi risiko kerentanan ikan tangkap non target (Carruthers et al, 2009) seperti single-fisheries fishing technique (Riskas et al, 2011). Alasan ini menjadi dasar acuan bahwa ternyata penggunaan alat handline masih rendah tekanannya terhadap baycath tuna. Selain itu perlu memperkuat kapasitas tata kelola dan juga compliance dengan aturan RFMO dalam pemanfaatan tuna dan baycacth (Gilman et al, 2011) serta perlindungan ekosistem (Gilman at al, 2014) yang menjadi isu lingkungan.

\section{KESIMPULAN}

Jenis ikan tangkapan dari alat tangkap pancing handline untuk kelompok ikan retain (non target) utama yaitu baby tuna, lemadang, cakalang, layaran dan pedang. Ikan ini tertangkap bersamaa dengan operasi penangkapan ikan target. Kegiatan penangkapan dengan alat tangkap handline relatif memiliki resiko rendah (low vulnerable) terhadap semua jenis retain. Data ini menunjukan bahwa alat tangkap handline tidak menyebabkan terjadinya potensi penurunan stok diperairan. Penggunaan alat tangkap ini juga mengindikasikan stok masih bisa di kelola dan tekanan penangkapan handline masih bisa di kendalikan hingga stok berkelanjutan.

Ucapan Terima Kasih: Terima kasih kami sampaikan kepada WWF-Indonesia atas izinnya dalam publikasi ini dan team yang sudah berkerja diantaranya Desti, Helmy, Burhan, Jaun, Silvia, Devi dan rekan rekan yang membantu penyelesaikan penelitian di dilokasi yang dikaji.

\section{DAFTAR PUSTAKA}

Arrizabalaga H., F.Dufour., L.Kell., G.Merino., L.Ibaibarriaga., G.Chust., X.Irigoien., J.Santiago.,I.Fraile., M.Chifflet.,N.Goikoetxea.,H.Murua., Y.Sagarminaga.,O.Aumont., L.Bopp., M. Herrera., J.M.Fromentin.,S.Bonhomeau. 2015. Global habitat preferences of commercially valuable tuna. Deep-Sea Research II 113 (2015) 102-112.

http://dx.doi.org/10.1016/j.dsr2.2014.07.001 
Asch R.G., W.W.L. Cheung, G.Reygondeau. 2018. Future marine ecosystem drivers, biodiversity, and fisheries maximum catch potential in Pacific Island countries and territories under climate change. Marine Policy 88 (2018) 285-294. http://dx.doi.org/10.1016/j.marpol.2017.08.015

Bartram P.K, J.J Kaneko., K K-Nakamura. 2010. Sea turtle bycatch to fish catch ratios for differentiating Hawaii longline- caught seafood products. Marine Policy 34 (2010) 145-149. doi:10.1016/j.marpol.2009.05.006

Belhabib D, V.W.Y. Lam, W.W.L. Cheung. 2016. Overview of West African fisheries under climate change: Impacts, vulnerabilities and adaptif responses of the artisanal and industrial sectors. Marine Policy 71 (2016) 15-28. http://dx.doi.org/10.1016/j.marpol.2016.05.009

Carruthers E.H., D.C. Schneider. JD. Neilson. 2009. Estimating the odds of survival and identifying mitigation opportunities for common bycatch in pelagic longline fisheries. Biological Conservation 142 (2009) 2620-2630. doi:10.1016/j.biocon.2009.06.010

Carruthers E.H, Neis B. 2011. Bycatch mitigation in context: Using qualitative interview data to improve assessment and mitigation in a datarich fishery. Biological Conservation 144 (2011) 2289-2299. doi:10.1016/j.biocon.2011.06.007

Davies. TK, C C. Mees. E.J. Milner-Gulland. 2015. Second-guessing uncertainty: Scenario planning for management of the Indian Ocean tuna purse seine fishery. Marine Policy 62 (2015) 169177. http://dx.doi.org/10.1016/j.marpol.2015.09.019

Frédou F.L., T. Frédou, D. Gaertner.,M. Potier., P. Bach., P. Travassos., F. Hazin., L. Kell., F. Ménard. 2016. Life history traits and fishery pattern $s$ of teleosts caught by the tuna longline fishery in the South Atlantic and Indian Oceans. Fisheries Research 179 (2016) 308-321.

http://dx.doi.org/10.1016/j.fishres.2016.03.013

Frédou FL., L.Kell., T.Frédou., D.Gaertner., P.Bach., P.Travassos., F.Hazin., F.Ménard., M.Potier. 2017. Vulnerability of teleosts caught by the pelagic tuna longline fleets in South Atlantic and Western Indian Oceans. Deep-Sea Research
Part II $140 \quad$ (2017) 230-241. http://dx.doi.org/10.1016/j.dsr2.2016.10.008

Gilman EL. 2011. Bycatch governance and best practice mitigation technology in global tuna fisheries. Marine Policy 35 (2011) 590-609. doi:10.1016/j.marpol.2011.01.021

Gilman EL., M Owens., T Kraft. 2014. Ecological risk assessment of the Marshall Islands longline tuna fishery. Marine Policy 44 (2014) 239-255. http://dx.doi.org/10.1016/j.marpol.2013.08.029

Hahlbeck N., K L. Scales., H. Dewar., S. M. Maxwell., S. J. Bograd.,E.L.Hazen. 2017. Oceanographic determinants of ocean sunfish (Mola mola) and bluefin tuna (Thunnus orientalis) by catch patterns in the California large mesh drift gillnet fishery. Fisheries Research $191 \quad$ (2017) 154-163. http://dx.doi.org/10.1016/j.fishres.2017.03.011

Huang H W, Y Swimmer, K Bigelow, A Gutierrez, DG. Foster. 2015. Influence of hook type on catch of commercial and bycatch species in an Atlantic tuna fishery. Marine Policy 65 (2016) 68-75.

http://dx.doi.org/10.1016/j.marpol.2015.12.016

Huang. H W., K.Ming Liu. 2010. Bycatch and discards by Taiwanese large-scale tuna longline fleets in the Indian Ocean. Fisheries Research 106 261-270. doi:10.1016/j.fishres.2010.08.005

Kirby D.S., C Visser., Q Hanich. Assessment of ecolabelling schemes for Pacific tuna fisheries. Marine Policy 43 (2014) 132-142. http://dx.doi.org/10.1016/j.marpol. 2013.05.004

Lopez J., G.Moreno., C.Lennert-Cody., M.Maunder., I.Sancristobal., A.Caballero., L.Dagorn. 2017. Environmental preferences of tuna and non-tuna species associated with

drifting fish aggregating devices (DFADs) in the Atlantic Ocean, ascertained

through fishers' echo-sounder buoys. Deep-Sea Research Part II 140 (2017) 127-138. http://dx.doi.org/10.1016/j.dsr2.2017.02.007

Pasparakis C., E M. Mager., J. D. Stieglitz., D. Benetti, M. Grosell., 2016. Effects of Deepwater Horizon crude oil exposure, temperature and developmental stage on oxygen consumption of embryonic and larval 
mahi-mahi (Coryphaena hippurus). Aquatic $\begin{array}{llll}\text { Toxicology } & 181 \quad \text { (2016) } & 113-123 .\end{array}$ http://dx.doi.org/10.1016/ j.aquatox.2016.10.022

Riskas KA, M.M.P.B. Fuentes, M.Hamann. 2016. Justifying the need for collaborative management of fisheries bycatch: A lesson from marine turtles in Australia. Biological Conservation $196 \quad$ (2016) 40-47. http://dx.doi.org/10.1016/j.biocon.2016.02.001.

Sunoko R, h.W. Huang. 2014. Indonesia tuna fisheries development and future strategy. Marine Policy 43 (2014) 174-183. http://dx.doi.org/10.1016/j.marpol.2013.05.011
Yonvitner, M Tamanyira, W Ridwan, A Habibi, Destilawati, Akmal SG. 2018. Kerentanan Perikanan Bycatch Tuna dari Samudera Hindia. Evidance dari Pelabuhan Perikanan Pelabuhanratu. Volume 2 No 1 hal 1-10. Jurnal Pengelolaan Perikanan Tropis (JPPT)

Williams A.J., V.Allain., S.J. Nicol., K.J. Evans., S.D. Hoyle., C. Dupoux., E.Vourey., J.Dubosc. 2015. Vertical behavior and diet of albacore tuna (Thunnus alalunga) vary with latitude in the South Pacific Ocean. Deep-Sea Research II 113 (2015) 154-169. http://dx.doi.org/10.1016/j.dsr2.2014.03.010 